lites. University departments and other research organizations wishing to propose scientific experiments for incorporation in the programme are invited to communicate with the Assistant Secretary, The Royal Society, Burlington House, London, W.1.

\section{Milk Marketing Board}

Is 1944 a plan was prepared for an artificial insemination service in all areas of England and Wales except those covered by the pioneer centre that had begun with Cambridge in November 1942. From a 'cow-population' map, territorially convenient blocks of 60,000 cows were ringed off as areas in which to build centres. Centres were to be located on the basis of thirty bulls to each centre (the maximum size because of the risk of foot-andmouth disease); on the estimate that ultimately 50 per cent of cows in each area would be offered for artificial insemination, and in the belief that 1,000 cows would be inseminated from each bull annually. The last two estimates, thought by many at the time to be far too optimistic, have been confirmed by subsequent history. Already, demand in some areas has resulted in more than ninety cows in every one hundred being inseminated, and the use of bulls is already more than twice the original estimate. In 1959-appropriately the centenary year of the publication of Darwin's "The Origin of Species"-the Milk Marketing Board has announced that 10 million cows have been produced by artificial insemination during the past fourteen years. The way this has been achieved, and the administrative structure of the Milk Marketing Board, is set out in a well-illus. trated publication called "Breeding 10,000,000 Cattle" (H.M.S.O.). The Board is rightly proud of its work and tells its story with lively enthusiasm. The fact that a cattle raiser can now breed for a change in the market merely by lifting a telephone is a tribute to the Board and the adaptable British farmer.

\section{New Bell Laboratories}

A NEW laboratory, costing 20 million dollars, will be built by Bell Telephone Laboratories at Holmdel, New Jersey, to meet the expanding need for research and development. Bell Laboratories is the research and development organization for the Bell Telephone System, and employs nearly 11,000 people. The new building will be on a 430 -acre site which has been owned by Bell Laboratories since 1929; it has been designed by Eero Saarinen. The first portion of the building is expected to be occupied by late 1961 .

\section{Journal of Molecular Biology}

ThIs journal is to be published six times a year by the Academic Press, Inc. (London), Ltd. (1, No. 1; April 1959. Subscription £5 per volume), and although published in English, papers in French and German will be accepted. The study of molecular biology attracts scientists from numerous disciplines and with its rapid expansion the problem of correlating results obtained by the specialist has become increasingly difficult. The advent of this new journal with an editorial policy of publishing papers on "the nature, production and replication of biological structure at the molecular level and its relationship to function" should be of great value to workers in this field. With one exception the eight papers and two letters in the first number of the Journal of Molecular Biology fall into the framework of molecular biology as defined in the instructions to authors. It is to be hoped that the exception does not repre- sent the thin end of the wedge and that the editors will in future restrict publication to papers dealing with molecular biology and not allow the periodical to develop into another journal of general biochemistry, of which there are already a sufficient number.

\section{The United States National Museum}

THE annual report of the United States National Museum for 1957-58 (pp. iv + 150. Washington, D.C. : Government Printing Office, 1958) records that rapid progress in planning the building for the Museum of History and Technology permitted erection to start in the summer of 1958. The building will be of a rectangular shape having an extended platform to form a terrace at first-floor level. It is significant to note that planning for the interior was undertaken by the architects from draft designs and details submitted by the Museum staff. This is the fifth year of the modernization programme, and the Halls of Health, North American Indian and Eskimos, native peoples of America, and military history have been dealt with. A striking exhibit is that depicting the home life of an average Arapaho Indian family some seventy-five years ago: while the warrior and his wife entertain visitors within a completely furnished tipi, the children play with toys outside and a woman prepares pemmican.

\section{Museum and Art Gallery, Durban}

THe annual report of the Museum and Art Gallery at Durban for 1957-58 (pp. 19. Durban: Durban Museum and Art Gallery, 1958) states that, in spite of a staff below establishment, much work on display for the public and the re-housing of the scientific research collections has been carried out during the year. The group showing the white-tailed wildebeest and warthog has been re-designed, and work has commenced on the Kruger Park waterhole exhibit. Owing to the vacant keepership in the Art Gallery, work in that branch of the service has been virtually at a standstill, although a few temporary exhibitions have been arranged. In the Old House Museum the court dress and accessories of Sir James L. Hulett have been placed on exhibition, and an interesting tollgate erected in Durban in 1867 has been re-erected in the grounds.

\section{U.S. Atomic Energy Commission: Grants for Training in Radioisotope Technology}

Mr. JoHn A. MoCone, chairman of the U.S. Atomic Energy Commission, has announced that grants amounting to 251,704 dollars to twelve American colleges and universities will be made for education and training in radioisotope principles and technology. An increase in the number of technical graduates who are able to use radiation as an industrial tool is expected to contribute significantly to the expanding uses of radioisotopes and radiation.

The grants are the first of a series of awards to be made under the Commission's new radioisotope technology training programme. The first series also includes a grant to the University of California, for the purchase of equipment to be used in three industrial radioisotope training courses this summer at Berkeley. Further information can be obtained from the Director, Office of Isotopes Development, U.S. Atomic Energy Commission, Washington 25, D.C. 